\title{
PENERAPAN TEKNOLOGI PRODUKSI MAKANAN OLAHAN UNTUK PENGEMBANGAN USAHA KECIL DAN MENENGAH DI KOTA BANDUNG
}

\author{
Muhammad Sigit Cahyono', Muhamad Ali Sukrajap², Dewi Handayani Harahap ${ }^{3}$ \\ ${ }^{1}$ Program Studi Teknik Perminyakan, Fakultas Teknik \\ ${ }^{2}$ Program Studi Manajemen, Fakultas Ekonomi \\ ${ }^{3}$ Program Studi Psikologi, Fakultas Psikologi \\ Universitas Proklamasi 45 \\ *Email korespondensi : dewipsikologi17@gmail.com
}

\begin{abstract}
Abstrak
Wisata kuliner merupakan hal yang menjanjikan saat ini sehingga pemerintah mendorong peningkatan produksi makanan olahan melalui pengembangan teknologi produksi makanan olahan. Kota Bandung terkenal dengan sebagai salah satu pusat kuliner di Indonesia. Pentingnya teknologi tepat guna tersebut diharapkan bisa meningkatkan kualitas dan kuantitas produksi makanan olahan. Program penerapan teknologi tepat guna diharapkan menghasilkan paket teknologi produksi makanan olahan tepat guna yang bisa dimanfaatkan oleh mitra UKM untuk meningkatkan kapastitas produksi dan pendapatan. Metode yang dilakukan adalah pengembangan teknologi produksi makanan olahan tepat gunamulai dari mengindentifikasi kebutuhan rill mitra terkait operasional produksinya, merancang dan membuat mesin, melakukan pengujian terhadap mesin yang dibuat, melakukan pelatihan dan pendampingan kepada pelaku UKM usaha produksi makanan olahan. Hasil kegiatan ini yaitu dapat membantu mengatasi permasalahan produksi yang dihadapi UKM, meningkatkan jumlah produksi dan bekerja secara efektif dan efisien, sehingga dapat meningkatkan kesejahteraan pelaku UKM pada khususnya dan masyarakat sekitar pada umumnya.
\end{abstract}

Kata Kunci : teknologi tepat guna, usaha kecil menengah, makanan olahan, Bandung

\begin{abstract}
Culinary tourism is promising at this time so the government is encouraging increased production of processed foods through the development of processed food production technologies. Bandung is famous as one of the culinary centers in Indonesia. The importance of appropriate technology is expected to improve the quality and quantity of processed food production. The program for implementing appropriate technology is expected to produce a package of appropriate processed food production technologies that can be utilized by UKM partners to increase production capacity and income. The method used is the development of appropriate processed food production technology ranging from identifying the real needs of partners related to their production operations, designing and making machines, testing the machines made, conducting training and mentoring to UKM of processed food production businesses. The results of this activity can help overcome the production problems faced by UKM, increase the amount of production and work effectively and efficiently, so as to improve the welfare of UKM in particular and the surrounding community in general.
\end{abstract}

Keywords: appropriate technology, small and medium businesses, processed food, Bandung

\section{Latar Belakang Masalah}

Perkembangan sektor industri dalam pembangunan di Indonesia tidak terlepas dari peranan dan keberadaan industri kecil. Dengan demikian upayapeningkatan pengembangan 
industri merupakanlangkah yang tepat untuk memacu pertumbuhan ekonomi daerah. Selain itu untuk membuka kesempatan kerja, keberadaan industry kecil juga sebagai penopang ekonomi kerakyatan[1].

Usaha Mikro Kecil Menengah (UMKM) di Indonesia memegang peran pentingdalam perekonomian Indonesia.Fleksibilitas yang dimiliki UMKM telah terbukti padasaat krisis moneter melanda negara-negara di belahan Asia tahun 2007/2008, UMKMtetap eksis dan mampu menjaga keberlangsungan usaha. Namun seiring perkembanganjumlah UMKM dari tahun ke tahun yang semakin bertambah, di sisi lain ada hal-halyang lama kelamaan mempengaruhi perkembangan UMKM itu sendiri diantaranyaterjadi penurunan atau kemunduran usaha yang dialami para pelaku UMKM. Hal inidisebabkan faktor internal misalnya kemampuan sumber daya manusia mengelola usahadalam berbagai bidang manajemen usaha seperti kemampuan dalam bidang pemasaran,teknis operasional, keuangan/pendanaan, dan bidang administrasi/akuntansi[2].

Usaha Kecil Menengah memegang peranan sangat penting dalam menunjang perekonomian suatu daerah. Kehadiran UKM bukan saja untuk peningkatan pendapatan tapi juga dalam rangka pemerataan pendapatan. Hal ini bisa dimengerti karena sektor UKM melibatkan banyak orang dengan beragam usaha. Pemerintah sudah mempunyai komitmen memberdayakan ekonomi kerakyatan dalam hal ini UKM dan koperasi. Namun misi ini sempat belum terlaksana dengan baik, seiring dengan sikap pemerintah yang masih mengandalkan usaha besar sebagai motor pertumbuhan ekonomi.

Penelitian mendapatkan hubungan yang erat antara pemberdayaan UKM dengan pertumbuhan ekonomi daerah. Menurut Schmitz[3], UKM mampu tumbuh lebih cepat dari usaha besar bila diberi peluang. Di Jepang, Jerman, Swedia, dan Italia usaha kecil elektronika, mampu melakukan penemuan, inovasi, dan bisa efisiensi. Schmitz percaya bahwa usaha kecil dan menengah akan mendominasi dan mendorong perkembangan ekonomi suatu bangsa, dengan syarat mereka mampu meningkatkan efisiensi dan daya saingnya.

Sektor UMKM di Indonesia, umumnya mempunyai ciri-ciri sebagai berikut : kegiatan usaha tidak terorganisasi secara baik, karena timbulnya unit usaha tidak mempergunakan fasilitas/kelembagaan yang tersedia, tidak mempunyai izin usaha, pola kegiatan usaha tidak teratur baik dalam arti lokasi maupun jam kerja, pada umumnya kebijakan pemerintah untuk membantu golongan ekonomi tidak sampai ke sektor ini. Umumnya UMKM di Indonesia masih dihadapkan pada berbagai permasalahan yang menghambat kegiatan usahanya. Berbagai hambatan tersebut meliputi pemasaran, keterbatasan finansial, keterbatasan SDM berkualitas, masalah bahan baku, keterbatasan teknologi, infrastruktur pendukung dan rendahnya komitmen pemerintah[4].

Pengelolaan UKM yang baik juga dilihat dari beberapa faktor yang diidentifikasi dalam lingkungan internal perusahaan[5] : (1)Sumber Daya Manusia, yaitu suatu proses untuk memperoleh, melatih, menilai, dan memberikan kompensasi kepada karyawan, serta memperhatikan hubungan kerja dengan karyawan, (2)Keuangan, yaitukeputusan investasi dan keputusan pembiayaan, (3) Produksi dan Operasi, yaitu semua aktivitas yang mengubah input menjadi barang dan jasa, (4) Pemasaran, yaitu proses pendefinisian, pengantisipasian, penciptaan, serta pemenuhan kebutuhan dan keinginan konsumenakan produk dan jasa

Salah satu jenis UKM yang sangat diandalkan dalam menunjang perekonomian daerah adalah usaha produksi makanan dan minuman.Usaha ini mampu bertahan dalam kondisi krisis ekonomi karena kebutuhan akan makanan akan terus ada. Selain itu, pola konsumsi masyarakat yang lebih modern mendorong mereka untuk mengkonsumsi makanan olahan.

Industri makanan dan minuman merupakan salah satu industri yang mengalami perkembangan cukup pesat.Dari sisi produksi, industri makanan dan minuman menjadi kontributor terbesar pembentukan Produk Domestik Bruto (PDB) sektor industri manufaktur 
nonmigaas Indonesia dengan share yang terus meningkat dari 28,6\% pada 2005 menjadi $36,3 \%$ pada 2012.

Tantangan yang dihadapi industri makanan dan minuman adalah pemenuhan bahan baku secara impor yang cukup besar (70\%-80\%), pergerakan rupiah yang cenderung terdepresiasi menjadi critical point. Tantangan dan kendala lain yang dihadapi industri makanan dan minuman dalam negeri adalah kenaikan biaya tenaga kerja dan listrik meskipun porsi dalam struktur biaya produksi relatif kecil $(<10 \%)$, kendala infrastruktur yang menimbulkan gangguan distribusi bahan baku dan barang jadi, dan persaingan dengan produk impor[6].

Salah satu usaha produksi makanan olahan yang berkembang di Kota Bandung adalah usaha Bunda Juminah Food. Usaha yang dirintis oleh Bu Juminah dibawah bendera CV Tiga Raja ini memproduksi makanan-makanan olahan seperti bandeng presto. Produk-produk yang dikembangkan oleh Bunda Juminah Food ini sudah cukup dikenal di Kota Bandung, bahkan pemasarannya sudah ke luar pulan Jawa seperti Batam, Riau, serta Samarinda.

Bunda Juminah Food merupakan salah satu jenis usaha mikro kecil dan menengah (UMKM) yang bergerak di bidang makanan dan minuman. Perusahaan yang didirikan oleh Bunda Juminah pada tahun 2013 ini menghasilkan berbagai macam jenis makanan, terutama olahan dari ikan bandeng seperti bandeng isi tanpa duri dan abon bandeng, serta produk makanan lain seperti bawang goreng, kering kacang teri, dan kolang-kaling.

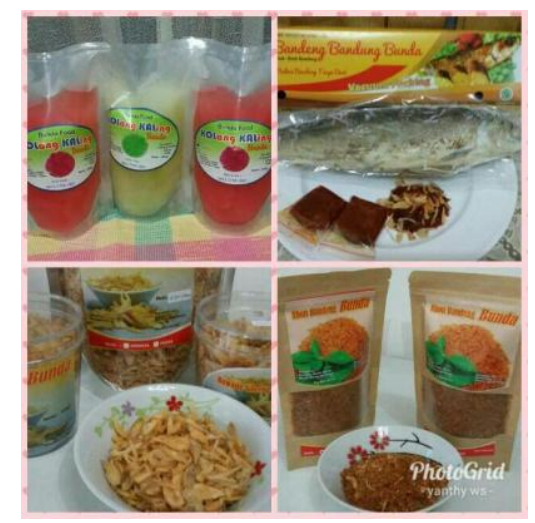

\section{Gambar 1. Beberapa Produk Olahan Makanan Bunda Juminah Food}

Untuk menghasilkan produk-produk tersebut, dibutuhkan bahan-bahan berupa bandeng segar, bawang merah Sumenep untuk bawang goreng, bawang merah Brebes untuk bumbu, cabe merah, minyak goreng, gula putih, bumbu rempah, telur, kelapa, dan santan. Sedangkan sebagai bahan bakar, digunakan LPG sebagai sumber energi untuk memasak semua adonan tersebut. Terkait omzet, jika dibuat rata-rata produksi Bunda Juminah Food mencapai 30 juta rupiah per bulan, sebelum dipotong biaya produksi dan lain-lain.

Produk-produk Bunda Juminah Food sudah berhasil menembus pasar lokal maupun luar daerah, namun mengalami kesulitan untuk memenuhi orderan karena keterbatasan tenaga dan sistem produksi mereka. Keterbatasan tersebut akan bisa diatasi dengan penggunaan peralatan tepat guna untuk produksi makanan olahan tersebut.

Program ini diharapkan bisa dirumuskan sebuah sistem pengembangan UKM makanan olahan melalui penerapan teknologi mesin pengolahan makanan tepat guna di masyarakat/pelaku usaha, hingga terjadi peningkatan kapasitas usaha yang secara otomatis akan meningkatkan pendapatan masyarakat. Melalui kolaborasi yang tepat antara perguruan tinggi, pemerintah daerah, dan industri, diharapkan penerapan teknologi produksi makanan olahan ini mampu dimanfaatkan menjadi produk yang bernilai dengan mutu terjamin dan bisa menghasilkan tambahan pendapatan bagi mitra dan masyarakat pada umumnya. 
Selain dari sisi produksi, hal lain yang tidak kalah penting adalah perlunya pendampingan dari sisi manajemen keuangan, pemasaran, sampai pengelolaan sumber daya manusia apabila usaha IKM tersebut berkembang besar nanti. Hal ini mutlak diperlukan agar perusahaan tersebut bisa bertahan di tengah persaingan dengan usaha lain, bahkan bisa menjadi leading company dalam penyediaan makanan olahan yang higienis dan berharga terjangkau.Program Penerapan Teknologi Tepat Guna kepada masyarakat ini, diharapkan bisa membantu meningkatkan kewirausahaan pelaku usaha produksi makanan olahan di Kota Bandung ini untuk meningkatkan kinerja dalam pengembangan usaha berskala UKM, baik dari sisi produksi, pemasaran, manajemen keuangan, sampai pengelolaan sumber daya manusia.

\section{Metode}

Metode pelaksanaan program yang diterapkan adalah serangkaian proses pengembangan teknologi mulai dari mengindentifikasi kebutuhan UKM, perancangan dan pembuatan mesin, pengujian operasional mesin, sosialiasi danserah terima mesin, sampai dengan pendampingan dan pelatihan operasional mesin pengolah makanan olahan tepat guna pada mitra UKM. Metode tersebut dapat dilihat pada gambar 2 diagram alir berikut.

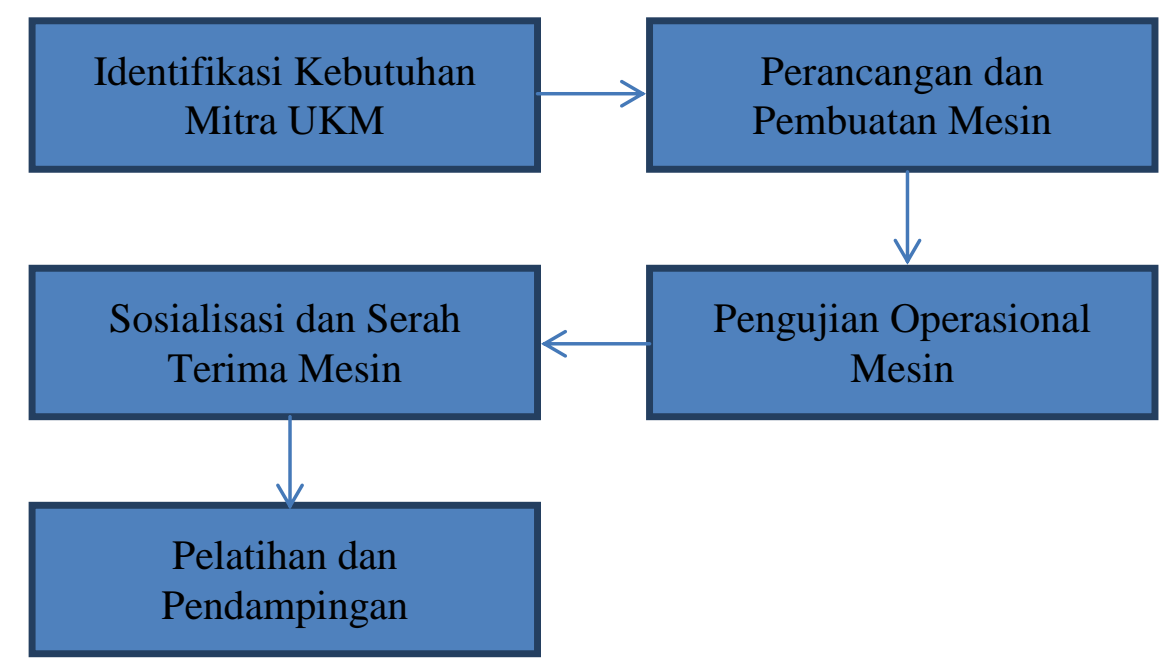

Gambar 2. Diagram Alir Kegiatan

Secara lengkap, kegiatan yang akan dilakukan adalah sebagai berikut :

a. Identifikasi Kebutuhan UKM Mitra

Identifikasi kebutuhan UKM Mitra ini dimaksudkan untuk mengetahui kapasitas produksi UKM sehingga peralatan yang dibuat nanti akan sesuai. Hal ini berkaitan dengan pendalaman data mengenai:

- Kapasitas produksi UKM Mitra. Untuk dapat melihat sejauhmana pengembangan dan peningkatan kapasitas produksi hasil yang akan disesuaikan dengan jangkauan pemasaran mitra UKM.

- Jangkauan Pemasaran Mitra. Dengan mengetahui jangkauan pasar UKM dapat disinkronkan dengan rencana kapasitas maksimum hasil yang dapat kembangkan pada mesin olahan tersebut.

- Profil UKM Mitra secara keorganisasian, untuk mendapat memetakan permasalahan Mitra dalam hal peningkatan kapasitas produksi dan jangkaun pemasaran mitra.

b. Perancangan dan Pembuatan Mesin. 
Setelah mendapatkan detail informasi mengenai profil mitra maka dilanjutkan pada modifikasi teknologi yaitu pengembangan mesin pengolahan yang dimulai dari desain perancangan kapasitas produksi dan pembuatan mesin.

- Mendesain pengembangan mesin produksi makanan olahan tepat guna. Melakukan redesain terhadap teknologi yang telah ada melalui peningkatan kapasitas produksi mesin produksi makanan olahan tepat guna.

- Membuat mesin produksi makanan olahan tepat guna. Membuat mesin produksi makanan olahan tepat guna berdasarkan dengan desain yang telah direkayasa sebelumnya.

c. Pengujian Operasional Mesin.

Setelah pembuatan mesin selesai dilakukan maka dilanjutkan dengan tahapan berikutnya yaitu melakukan pengujian terhadap operasional mesin tersebut.Tahapan pengujian ini dilakukan untuk melihat kehandalan dari mesin yang telah dibuat. Adapun langkahlangkah yang dilakukan adalah sebagai berikut:

- Melakukan pengujian operasional mesin di bengkel

- Melakukan pengujian operasional mesin di masyarakat

- Melakukan evaluasi terhadap hasil uji mesin di masyarakat

d. Sosialisasi dan Serah Terima Mesin

- Kegiatan penguatan kelembagaan dilakukan melalui proses sosialisasiuntuk penerapan mesin produksi makanan olahan tepat guna berskala UKM dengan melibatkan semua pihak yang terkait.

- Seiring dengan kegiatan sosialisasi, juga dilakukan kegiatan penyerah terimaan mesin dari pengusul ke mitra penerima dengan didampingi semua pihak yang terkait, baik kalangan pemerintahan, akademisi, UKM, sampai masyarakat sekitar.

e. Pelatihan dan pendampingan

- Untuk peningkatan kompetensi sumber daya manusia, terutama pelaku usaha produksi makanan olahan tepat guna di Kota Bandung dan warga masyarakat, dilakukan pelatihan proses produksi makanan olahan tepat guna dengan berbasis teknologi mesin produksi makanan olahan tepat guna sesuai dengan bagian masing-masing. Melalui pelatihan ini, diharapkan mereka memahami apa yang harus dilakukan di lapangan dalam mengimplementasikan program ini.

- Pendampingan dan pelatihan yang diberikan selain terkait dengan produksi, juga akan diberikan pada aspek manajemen keuangan, pembukuan, pemasaran, sampai manajemen pengelolaan SDM yang bekerja dan terkait dengan usaha Bunda Jumiah Food.

Sedangkan teknologi yang akan diterapkan adalah sebagai berikut:

1) Mesin spinner peniris minyak (jumlah : 1 unit)

- Dimensi : P.1.t 600 x 400 x $600 \mathrm{~mm}$

- Penggerak motor listrik 0.25 HP

- Kapasitas 5 kg/proses

- Bahan stainless steel

- Rangka siku 40

- Fungsi untuk meniriskan minyak pada produksi abon dan bawang goreng

2) Mesin Pengukus Ikan (presto) (jumlah : 1 unit)

- Dimensi : P.l.t 400 x 400 x $650 \mathrm{~mm}$

- Diameter tabung $350 \mathrm{~mm}$

- Kapasitas 10 kg/proses

- Bahan stainless steel tebal $2 \mathrm{~mm}$

- Kelengkapan : kompos LPG, pengukur tekanan \& suhu, safety valve

- Fungsi untuk mengukus ikan agar durinya bisa lunak (presto) 
3) Mesin pengembang kue (jumlah : 1 unit)

- Dimensi : P.1.t 800x600x1200 mm

- Kapasitas $15 \mathrm{~kg} / \mathrm{jam}$

- Jumlah rak 10 buah

- Pemanas Heater 500 Watt

- Bahan stainless steel

- Fungsi untuk mengembangkan adonan kue

4) Mesin pendingin makanan / Box Freezer (jumlah : 1 unit)

- Dimensi 1930 x 670 x $825 \mathrm{~mm}$

- Kapasitas 650 liter

- Daya 268 Watt

- Fungsi untuk menyimpan ikan dan bahan baku lainnya dalam kondisi dingin

5) Mesin pengaduk adonan / blender (jumlah : 1 unit)

- Varian 5 kecepatan

- Bahan tabung : kaca

- Fungsi untuk mengaduk adonan agar merata

6) Mesin pemasak / kompor (jumlah : 1 unit)

- Model burner besar

- Tekanan tinggi

- Kelengkapan : regulator tekan dan selang gas

- Fungsi untuk memasak adonan agar matang

\section{Hasil dan Pembahasan}

Hasil kegiatan yang telah dicapai pada kegiatan ini adalah pembuatan peralatan pengolahan makanan olahan dengan teknologi tepat guna, pengujian peralatan serta penyempurnaan peralatan tersebut. Selain itu, juga dilakukan kegiatan koordinasi kegiatan dan survei kesiapan mitra dalam menerima peralatan tersebut, serta sosialisasi dan serah terima teknologi tepat guna ini pada pelaku IKM dan warga masyarakat di sekitar lokasi mitra.

Hasil dari kegiatan-kegiatan tersebut adalah sebagai berikut:

1. Identifikasi Kebutuhan Mitra

- Langkah pertama dari program ini adalah melakukan kegiatan koordinasi dan survei ke lapangan pada Tanggal 3 Agustus 2019, untuk mengetahui kondisi mitra yang akan memanfaatkan bantuan peralatan tersebut.

- Mitra yang terlibat dalam kegiatan ini ada 2, yaitu Bunda Juminah sebagai pemilik UKM Bunda Juminah Food dan Ketua RT 04 RW 04 Bumi Panyileukan sebagai perwakilan warga dimana mitra bertempat tinggal dan beraktifitas.

- Kegiatan koordinasi dilakukan untuk mengetahui kesiapan mitra dalam menerima peralatan yang akan diberikan, misalnya ruangan yang dimiliki apakah cukup atau tidak, listrik di lokasi usaha apakah memungkinkan jika seluruh peralatan dioperasikan, serta kesiapan teknis lainnya seperti sumber daya manusia dan manajemen usaha.

- Sumber daya manusia yang dimiliki yaitu pekerja tetap yang aktif di Bunda Jumiah Food ada dua orang yang bekerja sehari-hari untuk produksi. Selain itu, saat ada orderan yang cukup besar, Bunda Juminah memberdayakan ibu-ibu anggota pengajian yang beliau asuh untuk membantu produksi. Kedepannya, jika peralatan yang baru sudah beroperasi dan produksi sudah meningkat, akan dilakukan penambahan pekerja produksi beberapa orang yang diambil dari warga sekitar, khususnya janda-janda yang membutuhkan tambahan nafkah untuk menghidupi keluarganya. Termasuk juga penambahan SDM khusus di bidang marketing untuk menambah jangkauan pemasaran dan memperluas pasar, baik secara offline maupun memanfaatkan media online agar 
produk-produk Bunda Juminah Food lebih dikenal tidak hanya diwilayah Bandung dan sekitarnya, tetapi juga ke seluruh penjuru negeri ini.

- Berdasarkan kondisi yang didapatkan dari hasil survei, dapat dirumuskan saran-saran sebagai berikut :

a) Perlu ditingkatkan daya listrik ruang usaha Bunda Juminah Food apabila produksi sudah berjalan optimal agar tidak mengalami gangguan saat berproduksi.

b) Perlu dioptimalkan pengoperasian mesin-mesin yang diterima nantinya agar bisa menghasilkan manfaat yang besar bagi perkembangan usaha Bunda Jumiah Food dan warga sekitar.

- Berdasarkan referensi penelitian yang dilakukan oleh[7], diketahui bahwa usaha mikro kecil dan menengah (UMKM) harus memperhatikan aspek kekuatan, kelemahan, peluang dan ancaman. Sektor usaha Kuliner terbentur pada faktor kelembagaan dan faktor pemasaran sehingga diperlukan adanya sinergi untuk bekerjasama antara semua sektor industri kreatif baik dengan pemerintah maupun dengan swasta.

- Selain itu hasil penelitian[8] mengenai hasil analisis SWOT terhadap makanan olahan dari kota Bandung, diketahui bahwa faktor eksternal berupa peluang yang mempengaruhi peningkatan penjualan di kota Bandung yaitu branding kota sebagai tujuan wisata kuliner, sedangkan ancaman tertingi dari makanan negara lain. Faktor internal sebagai kekuatan yaitu daya tarik menu yang ditawarkan, sedangkan faktor kelemahannya yaitu promosi, sehingga strategi yang cocok diterapkan yaitu strategi penetrasi pasar dan strategi peningkatan produk. Maka berdasarkan hal ini pelaksanaan program Penerapan Teknologi Tepat Guna kepada Masyarakat (PPTTG), sangat tepat diberikan kepada masyarakat UMKM di Kota bandung dalam rangka membantu mengatasi permasalahan yang dihadapi.

b. Penyiapan dan pengujian alat

- Tahap selanjutnya dari program ini adalah penyiapan peralatan, berupaalat penirirs minyak (spinner), pengaduk adonan bumbu, pengukus bandeng (presto), pengembang kue (proofing), box pendingin (chest freezer), serta kompor besar untuk memasak.

- Proses perancangan dilakukan selama satu minggu, untuk kemudian dilakukan proses pembuatan peralatan di bengkel rekayasa selama empat minggu.

- Kegiatan-kegiatan tersebut ditunjukkan dalam gambar 3 berikut ini:
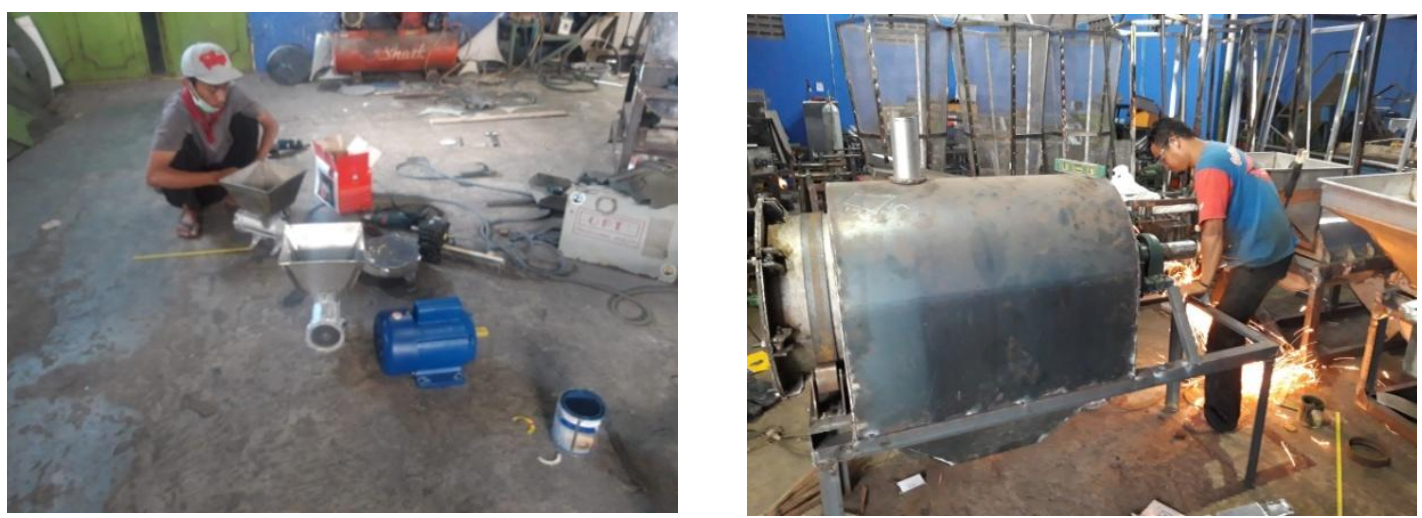

Gambar 3. Proses pembuatan alat di bengkel rekayasa

c. Pengujian operasional mesin

- Tahap berikutnya adalah pengujian awal peralatan tanpa menggunakan beban untuk mengetahui kondisi peralatan, apakah mengalami kendala ataukah sudah bisa digunakan. Pada saat pengujian awal alat peniris minyak, terjadi sedikit permasalahan 
dengan kecepatan putarnya yang terlalu lambat. Akan tetapi setelah dilakukan perbaikan, alat tersebut bisa beroperasi dengan baik.

- Setelah itu dilakukan kegiatan pengujian peralatan menggunakan beban masing-masing selama beberapa kali, sampai peralatan bisa dioperasikan dengan baik.

- Setelah pengujian berhasil, peralatan dibersihkan dan dikemas dengan baik untuk dikirimkan ke lokasi mitra penerima.

\section{d. Sosialisasi PPTTG}

Kegiatan ini dilakukan untuk memberi pemahaman kepada pengelola IKM Bunda Juminah Food dan perwakilan warga masyarakat RT 04 RW 04 Bumi Panyileukan tentang pentingnya pemberdayaan masyarakat dalam pengelolaan IKM makanan olahan ini. Selain itu, disampaikan juga tentang rencana peralatan yang akan diberikan termasuk metode pengoperasiannya agar mereka punya gambaran tentang manfaat dari program penerapan teknologi tepat guna (PPTTG).

Kegiatan ini dilakukan pada tanggal 23 Agustus 2019 di rumah Bunda Juminah dan dihadiri oleh pegawai beliau serta beberpa perwakilan warga sekitar. Sosialisasi tersebut diberikan oleh narasumber yang kompeten di bidang pemberdayaan masyarakat dan pengembangan IKM produk makanan olahan. Acara sosialisasi tersebut berjalan lancar dimana peserta bisa memahami seluruh materi yang disampaikan, serta adanya kesempatan untuk bertanya bisa membuat pemahaman mereka lebih dalam tentag program ini.Harapannya, mitra UKM dan warga masyarakat mempunyai gambaran yang jelas terkait program penerapan teknologi tepat guna ini.

e. Serah terima dan pelatihan

Kegiatan utama dari program penerapan teknologi tepat guna (PPTTG) ini adalah serah terima alat dan pelatihan.Acara dilakukan pada Tanggal 7 September 2019 di halaman rumah Bunda Juminah, sebagai penerima mesin-mesin tersebut. Dalam kesempatan ini, acara serah terima juga dihadiri anggota Komisi X DPR RI, perwakilan dari pemerintah Kota Bandung, kedua mitra serta warga masyarakat penerima bantuan mesin tersebut. Setelah acara serah terima, dilanjutkan dengan pelatihan pengoperasian peralatan untuk operator mesin-mesin tersebut, termasuk pelatihan peningkatan produktifitas UKM oelh narasumber yang kompeten di bidangnya. Menurut penelitian yang dilakukan[9], pelatihan yang diadakan sendiri tidak berdampak pelatihan secara parsial berpengaruh signifikan terhadap keberdayaan pengrajin batik, sedangkan penggunaan teknologi tepat guna secara parsial berpengaruh tidak signifikan terhadap keberdayaan pengrajin batik. Pelatihan dan teknologi tepat guna secara bersama-sama berpengaruh signifikan terhadap keberdayaan pengrajin batik artinya tingkat keberdayaan pengrajin batik ditentukan oleh pelatihan dan penggunaan teknologi tepat guna. Hal ini telah sejalan dengan proses yang dilakukan dalam program ini.

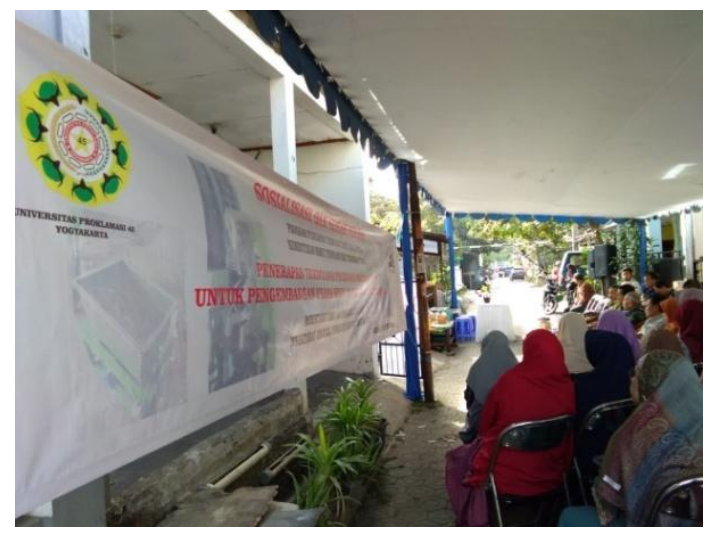

Gambar 4. Acara Serah Terima alat

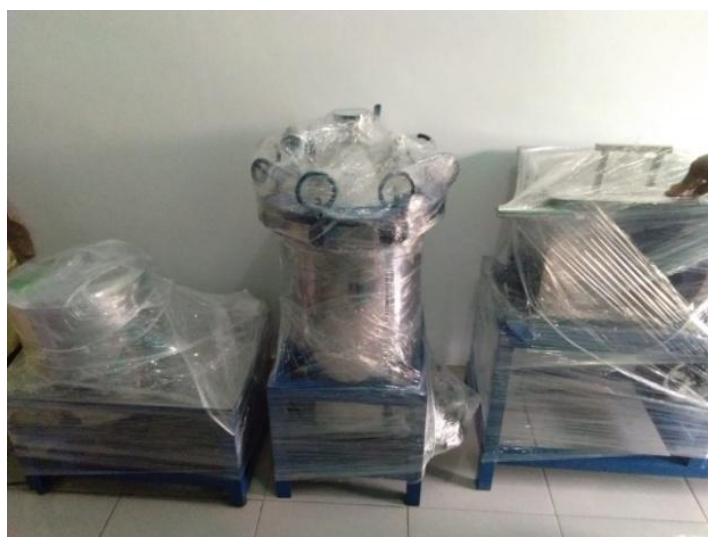

Gambar 5. Peralatan yang diserahterimakan 


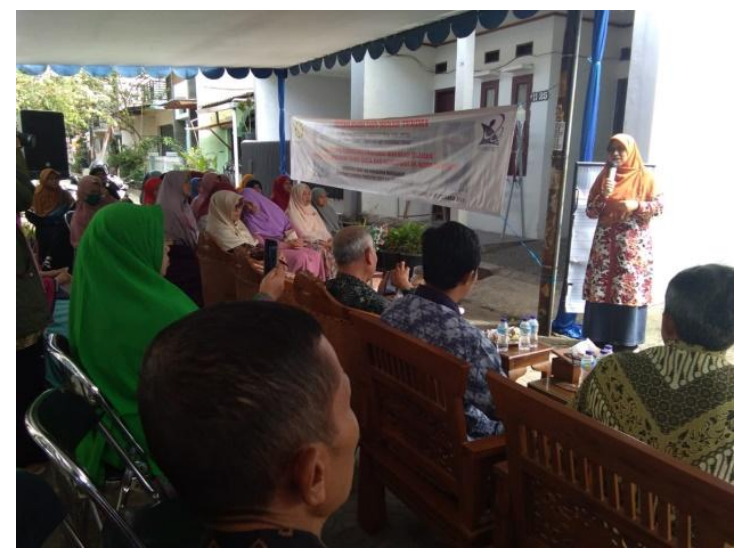

Gambar 6.Sambutan Anggota Kom X DPR RI

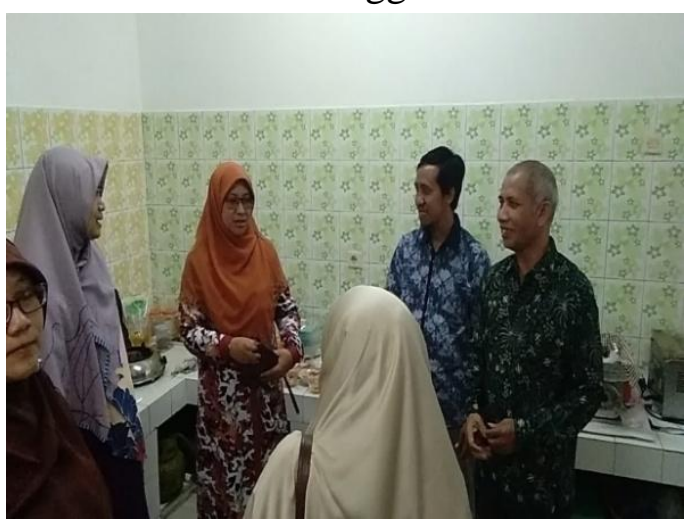

Gambar 8. Kunjungan ke ruang usaha

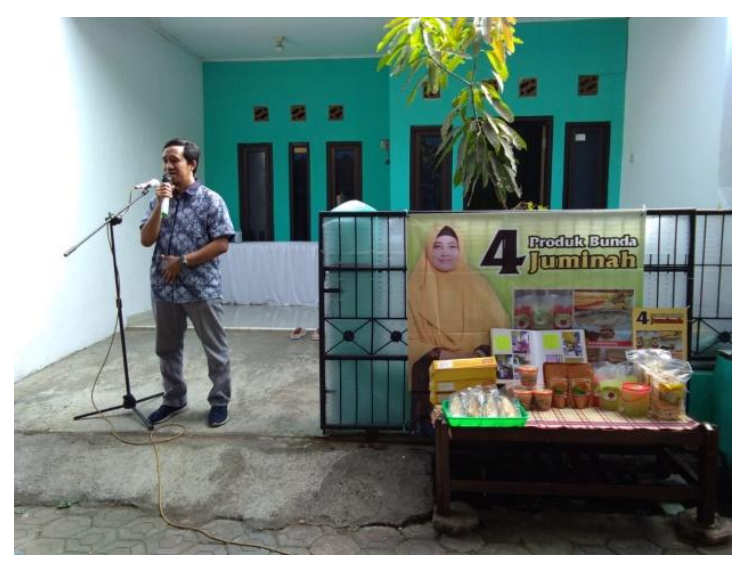

Gambar 7. Sambutan Ketua Tim Pengusul

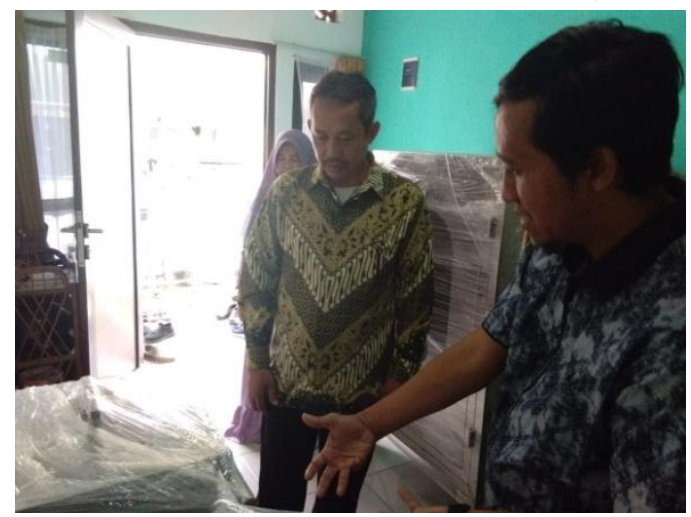

Gambar 9. Penjelasan prosedur kerja peralatan

\section{f. Evaluasi Kegiatan}

Evaluasi kegiatan dilakukan untuk mengetahui apakah output dari kegiatan pengabdian kepada masyarakat ini menghasilkan manfaat positif bagi mitra UKM dan masyarakat sekitarnya. Evaluasi ini dilakukan 2 bulan setelah mesin diserah terimakan ke mitra. Berdasarkan hasil evaluasi, dapat terlihat bahwa terjadi peningkatan kapasitas produksi dari Bunda Juminah Food, khususnya pada produk bandeng presto, dimana mengalami peningkatan omzet sebanyak $100 \%$, dari $50 \mathrm{~kg} / \mathrm{bulan}$ menjadi $100 \mathrm{~kg} / \mathrm{bulan}$. Peningkatan signifikan ini terutama disebabkan adanya tempat penyimpanan (box freezer) yang ukurannya jauh lebih besar daripada yang dimiliki sebelumnya, sehingga kemampuan stok bahan baku maupun produk menjadi lebih besar. Termasuk juga adanya tambahan mesin pengukus (presto) dengan kapasitas yang lebih besar secara otomatis menambah kapasitas produksi bandeng presto tersebut.

Sementara untuk produk lain, juga terjadi peningkatan meskipun bukan dari sisi kuantitas, tapi kualitas. Seperti produk bawang goreng, warnanya lebih cerah karena lebih terbebas dari minyak hasil penggorengan, serta tidak mudah tengik seperti dulu. Hal ini membuaut harga jual produk tersebut lebih meningkat meskipun tidak terlalu signifikan. Di sisi lain, adanya kenaikan kapasitas produksi tersebut tentu berkorelasi positif pada peningkatan jumlah tenaga kerja, dimana terjadi penambahan tenaga produksi sebanyak 2 orang, menjadi 4 orang, yang semuanya adalah warga sekitar khususnya yang berstatus janda. Begitu juga tenaga pemasaran yang juga bertambah, khususnya reseller produkproduk Bunda juminah Food yang mulai merambah ke luar kota Bandung bahkan sampai ke luar Jawa. Hal ini menunjukkan bahwa program penerapan teknologi tepat guna kepada masyarakat ini menghasilkan manfaat yang besar bagi mitra dan warga masyarakat sekitarnya. 


\section{Kesimpulan}

Berdasarkan pelaksanaan kegiatan pada program penerapan teknologi tepat guna (PPTTG) ini, dapat disimpulkan sebagai berikut :

1. Adanya bantuan mesin-mesin melalui program PPTTG ini telah meningkatkan kapasitas produksi dari UKM Bunda Juminah Food, sehingga bisa meningkatkan pendapatan mereka pada khsuusnya dan masyarakat sekitar pada umumnya.

2. Adanya peningkatan kapasitas dan pendapatan mitra maupun masyarakat ini menunjukkan bahwa program ini cukup berhasil sehingga bias diterapkan pada daerahdaerah lain di masa depan.

\section{Daftar Pustaka}

[1] Putra, S. (2017), Analisis Industri Pangan Sub Sektor Industri makanan Ringan Kue Bangkit dan Bolu (dengan Menggunakan Strukture Conduct Performance / SCP). JOM Fekon, Vol.4 No.1 (Februari) 2017.

[2] Mangantar, M., Adolfina, Baramuli, D.N. (2016).Usaha mikro makanan tradisionaldi kelurahan Dendengan dalam Kota ManadoTentang manajemen modal kerja.Jurnal LPPM Bidang EkoSosBudKum, Volume 3 Nomor 1 Tahun 2016Edisi Mei.

[3] Anggraeni, F.D., Hardjanto, I, \&Hayat, A. (2013). Pengembangan Usaha Mikro Kecil dan Menengah (UMKM) Melalui Fasilitasi Pihak Eksternal dan Potensi Internal. Studi kasus pada kelompok usaha "Emping Jagung" di Kelurahan Pandanwangi Kecamatan Blimbing, Kota Malang. Jurnal Administrasi Publik. Volume 1 no 6, hal 1286-1295.

[4] Rawis, J.E.O., Vicky.V.J., Arie, P.,Mirah, D. (2016). Analisis Keuntungan Usaha Kecil Kulinerdalam Upaya Pengembangan UMKM di Kota Manado (Studi Kasus Usaha Katering Miracle Ranotana Weru). Jurnal EMBAVol.4No.2Juni2016, Hal. 106-119

[5] David, F. R. (2009). Manajemenstrategi. Edisi Kesepuluh. Jilid 1. Jakarta: Salemba Empat

[6] Wijiati, I. dan Santosa, B. (2015), Pengaruh Ekonomi Industri Makanan Dan Minuman Di Indonesia Tahun 2009-2013, Media Ekonomi Vol. 23 No. 1 April 2015.

[7] Ananda, A.D, \& Susilowati, D. (2017). Pengembangan Usaha Mikro Kecil dan Menengah (UMKM) Berbasis Industri Kreatif di Kota Malang. Jurnal Ilmu Ekonomi. Volume X. Jilid X, hal 120-142.

[8] Fajri, I (2018). Strategi Peningkatan Penjualan Makanan OlahanTradisional Sunda Melalui Daya Tarik Produk Wisata Kuliner di The Jayakarta Bandung Suite Hotel \& Spa. Tourism and Hospitality Essentials (THE) Journal, Vol. 8, No. 1, Hal 45-56.

[9] Andarwati, M., Subiyantoro, E., \& Subadyo, T. (2018). Pengaruh Pelatihan dan Penerapan Teknologi Tepat Guna (TTG) Terhadap Keberdayaan Pengrajin Batik Tulis Ramah Lingkungan. Jurnal Briliant : Jurnal Riset dan Konseptual. Volume 3 no 3, hal 280-286. 